\title{
Effects of rapeseed oil duodenal infusion on dairy cow performances and blood metabolites during early lactation
}

\author{
Y Chilliard1', G Gagliostro1,2, A Ollier1', D Bauchart ${ }^{3}$ \\ with the technical assistance of E Girard, R Lefaivre, \\ C Legay, JN Rampon, G Sauvage \\ 1 Laboratoire de la Lactation, INRA, Theix, 63122 Ceyrat, France; 2 INTA, Balcarce, Argentina; \\ ${ }^{3}$ Laboratoire d'Etude du Métabolisme Energétique, INRA Theix, 63122 Ceyrat, France
}

Rapeseed-oil was continuously infused $(1.03 \mathrm{~kg} / \mathrm{d})$ into the duodenum of 6 multiparous fistulated cows ('O group'), from about 3 wk before to 3 wk after calving, in order to evaluate the metabolic effects of exogenous long-chain fatty acids, without disturbing rumen function, in cows that were mobilizing their body lipids. Six other cows were used as controls ('C group'). The diet was $60 \%$ corn silage and $40 \%$ concentrate. Groups $\mathrm{O}$ and $\mathrm{C}$ received 18 and $12 \%$ soybean meal, respectively. There was a between-group difference of $4.1 \mathrm{~kg} \mathrm{milk} / \mathrm{d}$ in previous peak lactation yield.

Milk yield during wk 3 of experimental lactation was significantly lower in group $\mathrm{O}$ (27.7 vs $33.8 \mathrm{~kg} / \mathrm{d}, P<0.05$ ), but not if corrected for previous milk potential. Milk fat and protein contents were nonsignificantly increased $(+1.3 \mathrm{~g} / \mathrm{l})$ and decreased $(-1.0 \mathrm{~g} / \mathrm{l})$, respectively. Oil-free dry matter intake was lower in group $O$ (12.7 vs $15.2 \mathrm{~kg} / \mathrm{d}, P<0.05$ ), but absorbed metabolizable energy, including oil, was not different (39.4 and $41.8 \mathrm{Mcal} / \mathrm{d}$, in groups $\mathrm{O}$ and $\mathrm{C}$ ). Apparent intestinal digestibility of oil fatty acids was calculated to be $68 \%$, but that of oil lipids was only $46 \%$, due to increased endogenous excretion $(+223 \mathrm{~g} / \mathrm{d})$ of unsaponifiable lipids.
Total organic matter digestibility was not changed.

Empty body weight loss (after rumen emptying on $d 2$ and 21 after calving) was the same $(58 \mathrm{~kg})$ in both groups, as well as the decrease in subcutaneous adipose cell diameter $(-15$ and $-12 \mu \mathrm{m}$, in $\mathrm{O}$ and C). These facts contrasted with the difference in calculated energy balance during the same period $(-6.3 \mathrm{vs}-11.3 \mathrm{Mcal} / \mathrm{d}$, in $\mathrm{O}$ and $\mathrm{C}, P<0.05$ ), although calculations were made with coefficients very close to those observed by Vermorel et al (1990) during respiratory chamber experiments.

Neither plasma cholesterol, phospholipids or 3-OH-butyrate were affected by oil infusion. Preprandial (but not postprandial) plasma glucose was decreased $(0.46$ vs $0.55 \mathrm{~g} / \mathrm{l}, P<0.05$ ). Responses of plasma glucose and non-esterified fatty acids to an insulin challenge $(0.12 \mathrm{lU} / \mathrm{kg})$ were not significantly different between groups. Most oil effects in this early lactation experiment were in accordance with those observed in a previous mid-lactation experiment (Chilliard and Gagliostro, 1988).

Chilliard Y, Gagliostro G (1988) Reprod Nutr Dév 28 (suppl 1) 173-174

Vermorel M, Chilliard $Y$, Vernet J, Bauchart D, Ollier A (1990) Reprod Nutr Dev suppl 2 231s 